Original Research Paper

\title{
Determination of Morphometric Relationship and Condition Factors of Four Cichlids from Golinga Reservoir in Northern Region of Ghana
}

\author{
Elliot Haruna Alhassan, Daniel Nsoh Akongyuure and Francis Asumang \\ Department of Fisheries and Aquatic Resources Management, \\ University for Development Studies, P.O. TL 1882, Tamale, Ghana
}

\author{
Article history \\ Received: 08-01-2015 \\ Revised: 24-02-2015 \\ Accepted: 01-07-2015 \\ Correspondence Author: \\ Daniel Nsoh Akongyuure \\ Department of Fisheries and \\ Aquatic Resources \\ Management, University for \\ Development Studies, P. O. TL \\ 1882, Tamale-Ghana \\ E- mail: akongyuure2012@gmail.com
}

\begin{abstract}
Length-weight relationship and condition factor have severalapplications on fish biology, physiology, ecology and fisheries assessment. A six-month study was conducted from November 2013 to April 2014 to determine the length-weight relationship and condition factor of four major cichlids namely Oreochromis niloticus (Nile tilapia), Hemichromis fasciatus (Banded jewelfish), Sarotherodon galilaeus (Mango fish) and Tilapiazillii (Red-belly tilapia) to fill a knowledge gap and provide useful information for fisheries management and conservation in the Golinga reservoir using the length-weight based model. Samples were collected twice every month with gillnets from commercial fishermen. The length-weight relationship had a strong positive correlation $(r>0.8)$ for the four species. Oreochromis niloticus exhibited isometric growth $(b=3.07)$ whilst Hemichromis fasciatus $(b=2.81)$, Sarotherodon galilaeus $(b=2.91)$ and Tilapia zillii $(\mathrm{b}=2.75)$ showed negative allometric growth. Mean condition factor $(K)$ values were greater than one (3.66-4.88) for all the species and varied monthly. The study provided new information on lengthweight parameters for the four cichlids.
\end{abstract}

Keywords: Cichlids, Fisheries Management, Length-Weight, Condition Factor and Reservoir

\section{Introduction}

The natural fishery resources in Ghana are declining (Ofori-Danson et al., 2012), so there is a need to considerably increase fish production through strict management measures to bridge the widening gap between demand and supply. According to Le Cren (1951), knowledge of the length weight relationship of a fish is essential, since various important biological aspects, viz, general well-being of fish, appearance of first maturity, onset of spawning, etc., can be assessed with the help of condition factor, a derivative of this relationship. Moreover, the length-weight of fish is an important fishery management tool because it allows the estimation of the average weight of the fish of a given length group by establishing a mathematical relationship between the two (Beyer, 1987). As length and weight of fish are among the important morphometric characters, they can be used for the purpose of fish stock assessment. The objective of study was to generate current information on the length-weight relationship and condition factor of major cichlid species for sustainable exploitation and management of the Golinga reservoir fishery.

\section{Materials and Methods}

\section{Study Area}

The study was conducted in the Golinga community reservoir in the Tolon District of the Northern Region of Ghana. Golinga is about $12 \mathrm{~km}$ north-west of Tamale, the regional capital. The dugout has an area of about 18 ha. It is in the Guinea Savannah agro-ecological zone characterized by short trees with grass undergrowth. It experiences a unimodal rainfall regime which greatly influences the water level of the dugout. The annual rainfall averages between $950 \mathrm{~mm}$ and $1100 \mathrm{~mm}$. The maximum temperature is $42^{\circ} \mathrm{C}$ in March and April and a minimum of $15^{\circ} \mathrm{C}$ in January. The area falls within latitude $9^{\circ} 34^{\prime} 15.75^{\prime \prime} \mathrm{N}$ and longitude $1^{\circ} 01^{\prime} 21.13^{\prime \prime} \mathrm{W}$. Farming is the main occupation of the people but others engage in petty trading and fishing. 


\section{Data Collection}

Fish samples were collected from commercial gill net catches of fishermen twice in a month, from November 2013 to April 2014. The mesh size of the gill nets ranged from $4 \mathrm{~cm}$ to $7 \mathrm{~cm}$. The fishermen set their gill nets by 1800 GMT and retrieved them by 08 00 GMT the following morning. Fish species were identified using keys provided by Dankwa et al. (1999). Each fish was measured for Standard Length (SL) in $\mathrm{cm}$ and weighed to $0.1 \mathrm{~g}$ accuracy with a calibrated fish measuring board and a spring balance respectively. Monthly length-weight frequency (SL $\mathrm{cm})$ was compiled from the length-weight measurements of fish samples. In all, a total of 321 individuals were sampled for $O$. niloticus; 89 for $H$. fasciatus; 265 for S. galilaeus and 112 for T. zillii.

\section{Determination of Length-Weight Relationship}

Estimation of species length-weight relationship was calculated using the formula $\mathrm{W}=\mathrm{a} \mathrm{L}^{\mathrm{b}}$ (Le Cren, 1951). Where $W$ is weight (g) and $L$ is length $(\mathrm{cm}), a$ is a coefficient related to body form and $b$ is an exponent indicating isometric/allometric growth.

\section{Determination of Condition Factor}

Condition factor $(\mathrm{K})$ is the state of well-being of the fish, which was computed using the formula $\mathrm{K}=100$ $\mathrm{w} / \mathrm{L}^{3}$ (Pauly, 1983); where $\mathrm{W}=$ weight $(\mathrm{g})$ of a fish, $\mathrm{L}=$ total fish length $(\mathrm{cm})$.

\section{Data Analysis}

A least square regression plot was drawn using Microsoft Excel 2007 to compute for the $b$ value which was used to calculate for the condition factor $(\mathrm{K})$.

\section{Results}

\section{Length-Weight Relationship}

The scatter plots of length-weight relationship of the population of the fish species in the Golinga reservoir during the period of study are shown in Fig. 1-4. The standard Length (SL) of O. niloticus ranged between $6.2 \mathrm{~cm}$ and $19.0 \mathrm{~cm}$ and weighed between 5.1 $\mathrm{g}$ and $225.00 \mathrm{~g}$; SL of H. fasciatus ranged between 5.0 $\mathrm{cm}$ and 12.0 and weighed between $9.0 \mathrm{~g}$ and $76.0 \mathrm{~g}$. The standard length of $S$. galilaeus varied between 5.5 and $14 \mathrm{~cm}$ and the weight ranged between 12 and 120 $\mathrm{g}$ and the standard length of T. zillii varied between 6 and $12.5 \mathrm{~cm}$ and the weight ranged between 13.0 and 70.0 g. An exponential relationship was revealed between the Standard Length (SL) and body Weight (W) of O. niloticus, H. fasciatus, S. galilaeus and T. zillii and the equations describing these relationships were $\mathrm{W}=0.035 \mathrm{~L}^{3.073}(\mathrm{r}=0.889), \mathrm{W}=0.129 \mathrm{~L}^{2.554}(\mathrm{r}=$ $0.938), \mathrm{W}=0.061 \mathrm{~L}^{2.908}(\mathrm{r}=0.975)$ and $\mathrm{W}=0.0808$ $\mathrm{L}^{2.753}(\mathrm{r}=0.959)$ respectively Fig. $1-4$. The correlation coefficient $(\mathrm{r})$ was very strong in all four fish species. Table 1 shows the summary of length-weight relationship parameters and condition factor of the cichlid fishery of Golinga reservoir.

Table 1. Summary of length-weight relationship parameters and condition factor of the cichlid fishery from Golinga reservoir

\begin{tabular}{llllllll}
\hline Species & & & & & $\begin{array}{l}\text { Number of } \\
\text { individuals (N) }\end{array}$ & $\begin{array}{l}\text { Mean } \\
\text { condition factor (K) }\end{array}$ \\
\hline Oreochromisniloticus & $\mathrm{W}=0.035 \mathrm{~L}^{3.073}$ & 0.035 & 3.073 & Isometric & 0.889 & 321 & 3.66 \\
Hemichromisfasciatus & $\mathrm{W}=0.129 \mathrm{~L}^{2.554}$ & 0.129 & 2.554 & Allometric & 0.938 & 89 & 4.88 \\
Sarotherodongalilaeus & $\mathrm{W}=0.061 \mathrm{~L}^{2.909}$ & 0.061 & 2.909 & Allometric & 0.975 & 265 & 4.29 \\
Tilapiazillii & $\mathrm{W}=0.081 \mathrm{~L}^{2.753}$ & 0.081 & 2.753 & Allometric & 0.959 & 112 & 4.51 \\
\hline
\end{tabular}

$\mathrm{W}=$ Weight $(\mathrm{g}), \mathrm{a}=$ Intercept, $\mathrm{b}=$ Slope, $\mathrm{L}=$ Standard length $(\mathrm{cm}), \mathrm{r}=$ Correlation coefficient

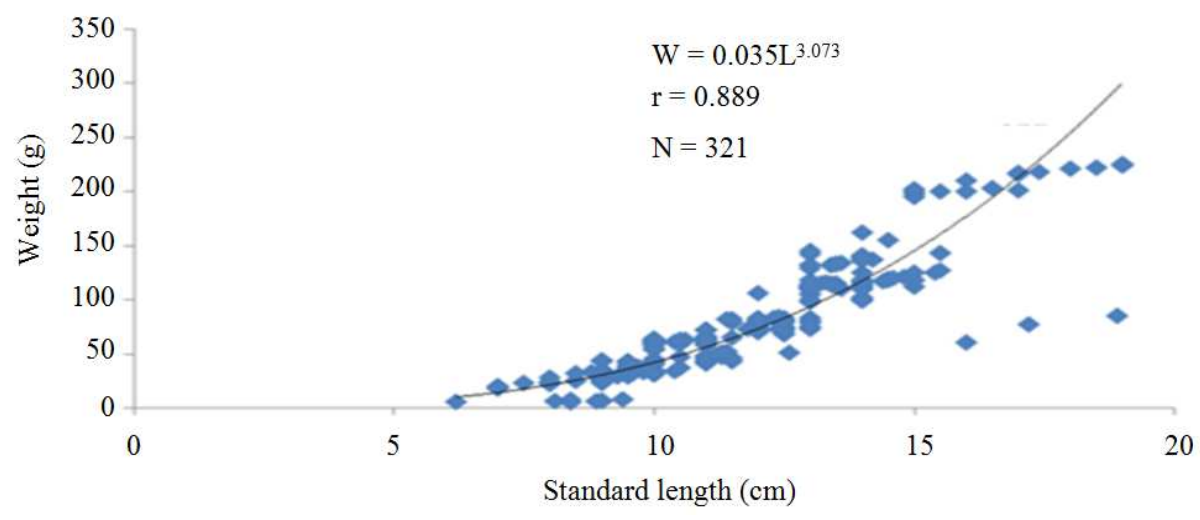

Fig. 1. Length-weight relationship of $O$. niloticus from the Golinga reservoir 


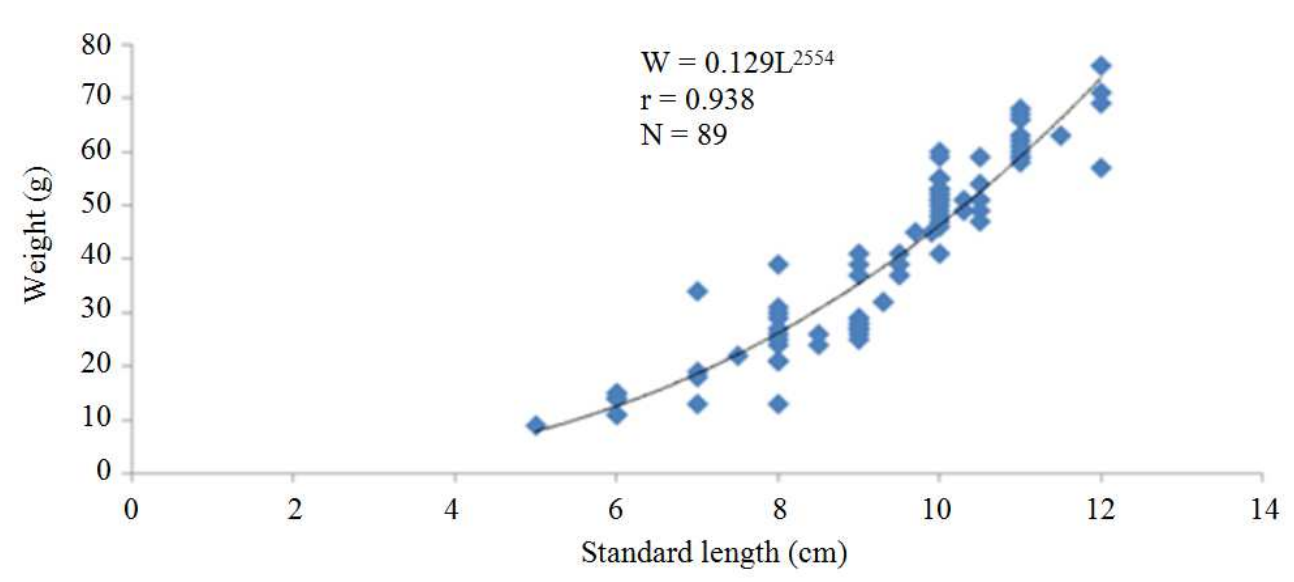

Fig. 2. Length-weight relationship curve of $H$. fasciatus from the Golinga reservoir

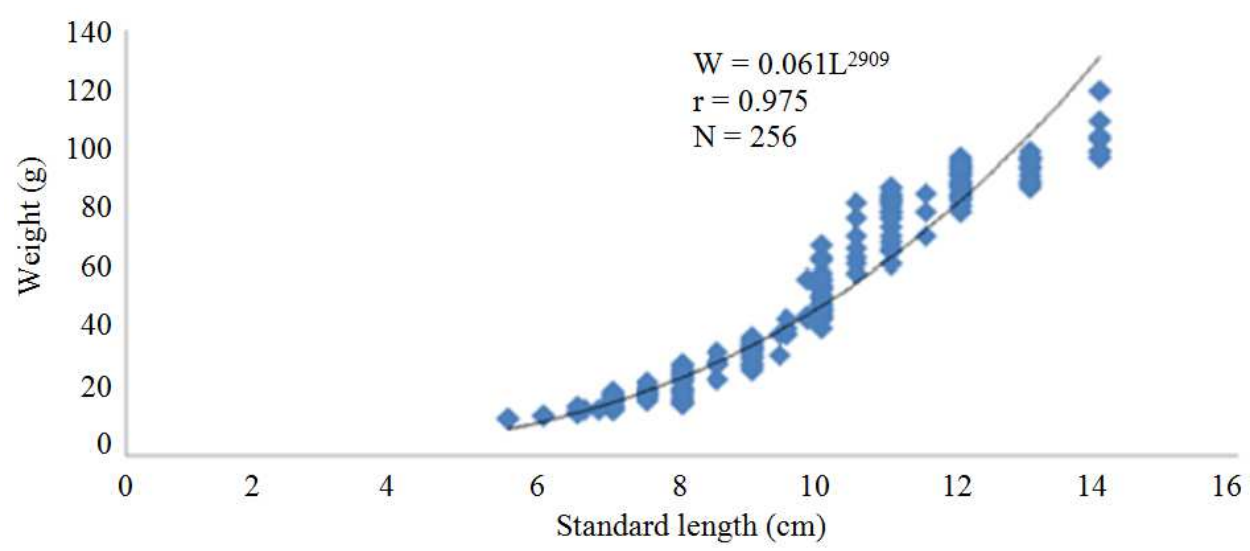

Fig. 3. The length-weight relationship curve for $S$. galilaeus from the Golinga reservoir

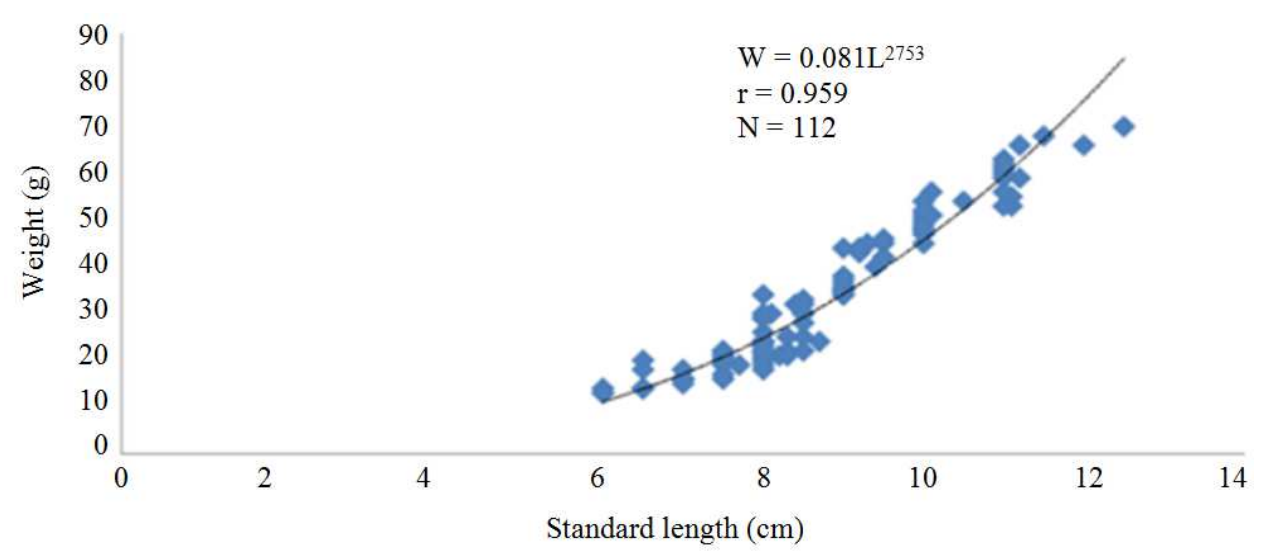

Fig. 4. The length-weight relationship curve for T. zillii from the Golinga reservoir

\section{Condition Factor}

Figure 5 shows the variation in the mean monthly (November, 2013-April, 2014) condition factors of the major cichlids studied in the Golinga reservoir. The condition factor of $O$. niloticus ranged from 2.45 to
4.65; those of $H$. fasciatus varied from 4.50 to $5.69 ; S$. galilaeus ranged from 3.44 to 4.75 and T. zillii ranged from 3.07 to 4.95 . Comparatively, H. fasciatus was in the best condition whilst $O$. niloticus was only good. All four species were in their good condition during the period of study. 


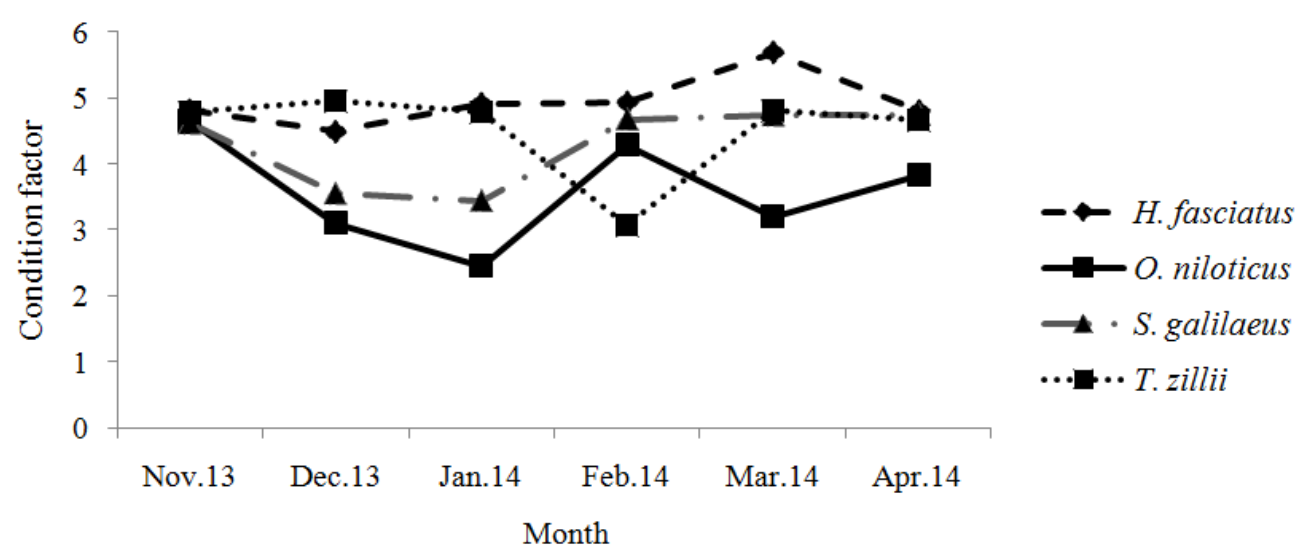

Fig. 5. Mean monthly variation in condition factor of major cichlids in the golinga reservoir during the study period

\section{Discussion}

\section{Length-Weight Relationship of Major Cichlids from Golinga Reservoir}

The length- weight relationship is very important for proper exploitation and management of the population of fish species (Pervin and Mortuza, 2008) and allows prediction of weight from length in yield assessment (Pauly, 1983). In fish, the weight is considered to be a function of length (Weatherley and Gill, 1987). In the present study, the regression equations and values of the correlation coefficient ' $r$ ' of the four fish species were suggestive of a close relationship between length and weight of the species (Table 1). For an ideal fish that shows isometric growth, the regression co-efficient (b) is 3.0 and populations in which the exponent differs significantly from 3.0 exhibit allometric growths (Beverton and Holt, 1966). Gayanilo and Pauly (1997) suggested that ' $b$ ' values may range from 2.5 to 3.5 which support the results of this study. Within the same species, variation in the exponent of length-weight relationships could be due to different stages in the ontogenetic development, differences in sex and differences in geographical location with the associated environmental conditions (Froese, 2006; Kraljevic et al., 1996).The length-weight relationship for O.niloticus was described by the relation $\mathrm{W}=0.035 \mathrm{~L}^{3.073}$ from the Golinga reservoir. The regression coefficient of 3.07 indicated isometric growth in $O$. niloticus as against allometric growth (1.2-1.4) reported by Imam et al. (2010) from Wasai reservoir in Kano, Nigeria. The finding from this study was also closely similar to the findings of Fafioye and Oluajo (2005) with bvalue of 3.04. Gayanilo and Pauly (1997) suggested that b values may range from 2.5 to 3.5 which support result of this study.

The negative allometric b value (2.55) obtained for $H$. fasciatus was similar to the study of Agboola and Anetekhai (2008). Koffi et al. (2014) reported positive allometric growth $(\mathrm{b}=3.16)$ for $H$. fasciatus from Aby Lagoon, Southeastern Côte d' Ivoire. The b value (2.91) in the length-weight relation, $\mathrm{W}=0.061 \mathrm{~L}^{2.909}$ for $S$. galilaeusindicated allometric (negative) growth. In agreement, Mahomoud et al. (2011) reported similar growth of this species in Rosetta branch of the Nile River, Egypt. Again, T. zilliishowed allometric (negative) growth $(b=2.75)$. In agreement, allometric (negative) growth $(b=2.69)$ was recorded in Lake Qauran and Edko as reported by Shalloof (2009). Similarly, negative allometric growth $(\mathrm{b}=2.30)$ of $T$. zillii was observed by Dan-Kishiya (2013) from Lower Usuma reservoir located in Abuja the federal capital territory of Nigeria and by Koffi et al. $(2014)(b=2.93)$ in Côte d' Ivoire. In contrast, isometric growth was reported for $T$. zillii in the Betania Reservoir in Colombia by Cala and Bernal (1997) and in the Guarapiranga Reservoir in Brazil by Krebs (1984). The length-weight relationship is a practical index of the condition of fish and may vary over the year according to several factors such as food availability, feeding rate, health, sex, gonad development, spawning period and preservation techniques (Begenal and Tesch, 1978).

\section{Condition Factor}

Condition factor studies describe the health and general well-being of a fish as related to its environment; hence it represents how healthy or plump the fishes are (Reynold, 1968). The condition factor of fishes has been reported to be influenced by a number of factors such as the onset of maturity (Hoda, 1987), spawning (De-Silva and Silva, 1979; Al-Daham and Wahab, 1991), sex and maturity (Gowda et al., 1987; Doddamani and Shanbouge, 2001) and pollution (Bakhoum, 1999; Devi et al., 2008). Condition factor is influenced by both biotic and abiotic environmental conditions and can be used as an index to assess the status of the aquatic ecosystem in which fish live (Anene, 2005). 
The monthly fluctuations in condition factor observed in this study in all the four species appeared to be influenced by gonadal development, availability of food and gastral activity. Changes in condition factor of fishes could be used to interpret various biological features such as fatness, food availability, reproductive activities and environmental health (Dadzie et al., 2000).

The condition factor mean values for O. niloticus (K $=3.66)$, S. galilaeus $(\mathrm{K}=4.29)$, T. zillii $(\mathrm{K}=4.51)$ and $O$. niloticus $(\mathrm{K}=3.58)$ recorded in this study were higher than values reported by Imam et al. (2010) and Achionye-Nzeh (2011) from reservoirs in Nigeria.

\section{Conclusion}

The length-weight relationship for $O$. niloticusand $H$. fasciatusin the Golinga reservoir were described by the relation $\mathrm{W}=0.035 \mathrm{~L}^{3.073}, \mathrm{r}=0.889$ and $\mathrm{W}=0.129 \mathrm{~L}^{2.554,} \mathrm{r}$ $=0.938$ respectively which shows that $O$. niloticus population in the Golinga reservoir were growing isometrically $(\mathrm{b}=3.07)$ and that of $H$. fasciatus were growing allometrically $(b=2.554)$.

Also, the length-weight relationship for $S$. galilaeusand T. zilliiin the Golinga reservoir were shown by the relation $\mathrm{W}=0.061 \mathrm{~L}^{2.9085}$ with $\mathrm{r}=0.9753$ and $\mathrm{W}=0.0808 \mathrm{~L}^{2.7534}$ with $\mathrm{r}=0.9595$ respectively. This indicates that both the population of $S$. galilaeusand $T$. zillii were growing allometrically with $\mathrm{b}$ values of 2.909 and 2.753 respectively.

The well-being of the four species studied was good since their condition factors were greater than one.

\section{Acknowledgement}

The research team is grateful to the fisher folk at Golinga for their fullest cooperation during the study. Our sincere gratitude also goes to both teaching and nonteaching staff of University for Development Studies, Nyankpala Campus for technical support and valuable assistance during the study.

\section{Funding Information}

Funding was done by authors themselves using salaries.

\section{Author Contributions}

Elliot Haruna Alhassan: Conception and design of research plan, Funding of research, Analysis and interpretation, Statistical analysis Critical revision of the article, Overall responsibility and Final approval of article.

Daniel Nsoh Akongyuure: Writing the article,Analysis and interpretation, Statistical analysis, Critical revision of the articleOverall responsibility and Final approval of article.
Francis Asumang: Funding of research, Data collection, Analysis and interpretation and Final approval of article.

\section{Conflict of Interest}

There is no conflict of interest that exists between authors.

\section{References}

Achionye-Nzeh, C.G., 2011. Reproductive strategies of the Cichlids in a small reservoir in Ilorin, Nigeria. Int. J. Biol. Chem. Sci., 5: 1688-1693.

Agboola, J.I. and M.A. Anetekhai, 2008. Length-weight relationships of some fresh and brackish water fishes in Badagry creek. Nigeria. J. Appl. Ichthyol., 24: 623-625. DOI: 10.1111/j.1439-0426.2008.01079.x

Al-Daham, N.K. and N.K. Wahab, 1991. Age, growth and reproduction of the greenback mullet, Liza subviridis (Valenciennes), in an estuary in Southern Iraq. J. Fish Biol., 38: 81-88. DOI: $10.1111 / \mathrm{j} .1095-8649.1991 . t b 03093 . x$

Anene, A., 2005. Condition factor of four cichlid species of man- made lake in Imo State, Southeastern Nigeria. Turk. J. Fish. Aquat. Sci., 5: 43- 47.

Begenal, T.B. and F.W. Tesch, 1978. Age and Growth. In: Methods for Assessment of Fish Production in Fresh Waters, Begenal, T. (Ed.), Blackwell Scientific, Oxford, ISBN-10: 0632001259, pp: 101-136.

Bakhoum, S.A., 1999. Comparative study on length-weight relationship and condition factor of the genus Oreochromis in polluted and non-polluted parts of lake Mariut, Egypt. Bull. Nat. Inst. Oceanogr. Fish (Egypt).

Beverton, R.J.H. and S.J. Holt, 1966. On the dynamics of exploited fish populations. Fisheries.

Beyer, J.E., 1987. On length weight relationships. Part I: Computing the mean weight of the fish of a given length class. Fish Byte, 5: 11-13.

Cala, P. and G. Bernal, 1997. Ecology and adaptations of Tilapianilotica L. in natural environments-Bethany Reservoir Case of Chilloa swamp system of the Magdalena River, Colombia, Dahlia. Revista. Asoc. Colomb. Ictiol., 2: 3-29.

Dadzie, S., F. Abou-Seedo and J.O. Manyala, 2000. Length weight relationship and condition factor of Pampusargentus E. in Kuwait waters. Kuwait J. Sci. Eng., 26: 123-136.

Dan-Kishiya, A.S., 2013. Length-weight relationship and condition factor of five fish species from a tropical water supply reservoir in Abuja, Nigeria. Am. J. Res. Comm., 1: 175-187.

Dankwa, H.R., E.K. Abban and G.G. Teugels, 1999. Freshwater fishes of Ghana: Identification, distribution, ecological and economic importance. Annls. Sci. Zool. 
De-Silva, S.S. and E.I.L Silva, 1979. Biology of young grey mullet, Mugilcephalus (Linneaus.). Populations of a coastal lagoon in Sri Lanka. J. Fish Biol., 15: 9-20. DOI: 10.1111/j.1095-8649.1979.tb03568.x

Devi, J.O., T.S. Nagesh, S.K. Das and B. Mandal, 2008. Length-weight relationship and relative condition factor of Pampusargenteus (Euphrasen) from Kakdwipesturine region of West Bengal. J. Inland Fish. Soc. India, 40: 70-73.

Doddamani, M.T.J.R. and S.L. Shanbhogue, 2001. Length-weight relationship and condition factor of Stolephorusbataviensis from Mangalore area. Indian J. Fish., 48: 329-332.

Fafioye, O.O. and O.A. Oluajo, 2005. Length-weight relationships of five fish species in Epe lagoon, Nigeria. African. J. Biotechnol., 4: 749-751. DOI: $10.5897 / A J B 2005.000-3136$

Froese, R., 2006. Cubelaw, Condition factor and lengthweight relationships: History, meta-analysis and recommendations. J. Applied Ichthyol., 22: 241-253. DOI: $10.1111 /$ j.1439-0426.2006.00805.x

Gayanilo, F.C. and D. Pauly, 1997. The FAO ICLARM Stock Assessment Tools (FISAT) reference manual. FAO Computer Information Series.

Gowda, G., S.L. Shanbougu and K.S. Udupa, 1987. Length-weight relationship and relative condition of Grey mullet, Valamugilsehci (Forskal), from Manglore waters. Indian J. Fish., 34: 340-342.

Hoda, S.S.M., 1987. Relative growth of body parts and length-weight relationship in Boleopthalmus dussumieri and B. deutatus of Jarachi Coast. Indian J. Fish, 34: 120-127.

Imam, T.S., U. Bala, M.L. Balarabe and T.I. Oyeyi, 2010. Length-weight relationship and condition factor of four fish species from Wasai Reservoir in Kano, Nigeria. Afr. J. Gen. Agric., 6: 125-130.

Koffi, B.K., S. Berté and T. Koné, 2014. Length-weight relationships of 30 fish species in aby lagoon, southeastern côte d' Ivoire. Curr. Res. J. Biol. Sci., 6: 173-178.
Kraljevic, M., J. Dulcuic, P. Cetinic and A. Pallaoro, 1996. Age, growth and mortality of the striped sea bream, Lithognathusmormyrus L., in the northern Adriatic. Fisheries Res., 28: 361-370. DOI: $10.1016 / \mathrm{S} 0165-7836(96) 00518-8$

Krebs, C.J., 1984. Ecology: The Experimental Analysis of Distribution and Abundance. 1st Edn., Harper Intellectual, New York, pp: 23.

Le Cren, E.D., 1951. Length-weight relationship and seasonal cycle in gonad weight and condition in perch (Percafluviatilis). J. Anim. Ecol., 20: 201-219. DOI: $10.2307 / 1540$

Mahomoud, W.F., A.M.M. Amin, K.F. Elboray, A.M. Ramadhan and M.M.K.O. El-Halfawy, 2011. Reproductive biology and some observation on the age, growth and management of Tilapia zilli G. from Lake Timsah, Egypt. Int. J., 3: 15-25.

Ofori-Danson, P.K., K. Apegyah, B. Asiedu, D.K. Atsu and E.H. Alhassan, 2012. Stock assessment study and fisheries management plan for the Bui Reservoir. Technical Report Submitted Bui Power Authority, pp: 106.

Pauly, D., 1983. Some Simple Methods for the Assessment of Tropical Fish Stock. 1st Edn., Food and Agriculture Org., Rome, ISBN-10: 9251013330, pp: 52.

Pervin, M.R. and M.G. Mortuza, 2008. Notes on lengthweight relationship and condition factor of fresh water fish, Labeoboga (Hamilton) (Cypriniformes: Cyprinidae). Univ. J. Rajshahi Univ., 27: 97- 98.

Reynold, T.D., 1968. The biology of the clupeids in the New Volta. Man-made Lakes. Accra Symposium. Ghana University Press, Accra.

Shalloof, K.A., 2009. Some observations on fisheries biology of Tilapia zillii G. and solea vulgaris Q. in lake qarun, Egypt. World J. Fish Marine Sci., 1: 20-28.

Weatherley, A.H., H.S. Gill and J.M. Casselman, 1987. The Biology of Fish Growth. 1st Edn., Academic Press, London, ISBN-10: 0127390553, pp: 443. 